\title{
FORGOTTEN FUNDAMENTAL MEANING OF GRAPHIC DESIGN IN INDONESIA
}

\author{
Yasser Rizky \\ Jurusan Desain Komunikasi Visual, School of Design, BINUS University \\ Jln. KH. Syahdan No. 9, Palmerah, Jakarta Barat 11480 \\ yr@yasserrizky.com; yasser_rizky@yahoo.com
}

\begin{abstract}
This article forwards questions about graphic design in Indonesia. Most people here, even graphic designers or graphic design academics do not know the answer to the question of what graphic design is. This condition brings out a new question of whether we really have a graphic design culture in Indonesia. If we trace back to the cause of it all, we will find a fact how a human interest discourse is still very rare in our country. Even when we find one, it tends to be a very subjective compilation of opinions instead of a strongly-based study. In further look, this is one of the reasons of why many graphic designers are stirred into ineffective work process causing unequal partnerships in their professional projects. For this, we have none to blame but ourselves and the system that we've created.
\end{abstract}

Keywords: fundamental meaning, graphic desaign

\begin{abstract}
ABSTRAK
Artikel menjelaskan pertanyaan tentang desain grafis di Indonesia. Kebanyakan orang di sini, bahkan desainer grafis atau akademisi sekali pun tidak tahu bagaimana menjawab pertanyaa tentang apakah desain grafis itu. Kondisi ini melahirkan pertanyaan baru mengenai apakah kita benar-benar memiliki budaya desain grafis di Indonesia. Jika kita menelusuri kembali ke akar permasalahannya, kita akan menemukan bahwa diskursus humaniora sangatlah sulit ditemukan di sini. Bahkan jika kita berhasil menemukan salah satunya, akan cenderung berwujud sebagai sebuah kompilasi opini-opini subjektif daripada studi dengan basis kuat. Dan saat kita melihat lebih jauh, inilah salah satu penyebab mengapa banyak desainer grafis terjebak di dalam proses kerja yang tidak efektif yang mengakibatkan tingkat kerjasama yang tidak setara di dalam pekerjaan profesional mereka. Untuk ini, tidak ada yang bisa disalahkan selain diri kita sendiri dan sistem yang telah kita ciptakan.
\end{abstract}

Kata kunci: arti fundamental, desain grafis 


\section{INTRODUCTION}

The reason why this question needs to be brought up is because after I've experienced professional and academic work in graphic design, it is very clear that our society still has a blurred understanding about graphic design.

Every designer and artist do have their own ideology about graphic design, but we should also have a fundamental understanding which we can hold onto as the basis to explore the possibilities of graphic design. Unfortunately in Indonesia, we tend to objectify design or place it as a communication in a very premature stage of understanding without knowing what it actually means. Maybe it is because the culture of discourse itself has not existed when every humanity study depends on discourse which can be seen from art, design, and philosophy. At the moment, many Indonesian writers try to discuss discourse about graphic design but they are done as opinions taking injections from other studies into graphic design without full understanding, resulting in cruelness to the graphic design itself. Plenty are astonished by the use of misplaced slogans of the contemporary writers with false understanding to words like post-modernism, deconstructive, etc, and stamp them as design styles.

Without realizing, we are teaching the next generation opinions with no clear fundamentals. We are teaching society the meaning of graphic design in a false course. And when designers design without common sense, without true understanding, then society will assume that this knowledge can be done and easily followed by anyone.

The setback of this understanding causes graphic design in Indonesia to be considered as a supporting element to marketing and promotion because of its implementation in the capital world. There are even some considering graphic design only as merely drawings, or in other word as an aesthetic addition which only works as decoration. This will make designers suffer lack of appreciation like underpayments, or even worse, to be the underdog of the professional world. But when we look again, there are sadly only few can be considered as qualified designers who understands what they do, and expands their knowledge itself. They place themselves in that situation. Design do help marketing, some even claim design as a non-art existence. But design is not marketing. Design and art are attached to one another because design was born from art.Design do add beauty, but design is not a mere decoration.

The question then continues, when graphic design products have already existed in Indonesia since a long time ago, has graphic design itself existed here? Then when we look at the most developed cities in Indonesia, why are there so many visual pollutants created by graphic designers themselves? Even universities in Indonesia with design major treats the research process based on an empirical understanding. This is a real proof that we do not truly understand what design is, because we still value it as a scientific knowledge. One thing that makes it harder, visuality of design is not tangible like it is in architecture or product design, so it is even more difficult for us to understand its value.

This weakness of discourse has blinded us with the history of graphic design and makes us running to different directions with no firm ground.Uncertainties and disbeliefs of graphic designers in Indonesia have artificially made us want to claim Indonesian design with definitions like "local content" or "nationalist design". The study of graphic design itself has never been properly discussed. These things diminish the spirit of design. Innovations and experimentations in Indonesia are very minimum when they are the vital factor in graphic design. No artwork has the ability to speak if it's boring. And how can we develop design knowledge if we do not understand it ourselves, even from the most fundamental parts. 
The basic understanding of graphic design itself in Indonesia is distorted up to the most fundamental part, making design culture as an absence in Indonesia, everything implemented instantly and forcefully without knowing the knowledge of design. This happens even in graphic design associations, even university institutions as well, whom are supposed to be the ones with the ability to develop this knowledge. This has also made the industrial world of graphic design comes to a chaos that is very vital and unhealthy because we do not have design culture yet.

This short article is a small effort so that designers and graphic design teachers would remind those fundamental basics of graphic design so that teachers and students will not need to lose the standing ground in developing this knowledge.

\section{METHOD}

Because it is intended to create a final result in the form of theoretical thinking, then this study uses literature study methods from several sources.

\section{DISCUSSION}

In this short article, the writer is trying to clarify a layered and complex thinking. Perhaps its mistake lies on the explanation of the word "design is". Design and its understanding as always changed and from many differences sees graphic design has several fundamental points that can be used as references for explanations.

\section{Disegno}

Etymologically, the work "art” that we know is from "Art”, in Latin: "Ars” which means "skill", technical skill, "techne". "Design" comes from the Latin word "Designare", Italian: "Designo". In the Art Theory discussion A Historical Introduction (Williams, 2004) expresses his opinion about design (designo). "In Idea of Painters, Sculptures \& Architects (1607) Federico Zuccaro tries to show how the whole of art, indeed, all arts, are based upon the single principle of designo....developing Vasari's concept of designo as a mental activity \& as the principle that unites the art of painting, sculpture \& architecture (1955)...designo is nothing less than the fundamental principle of all thought...designo must be understood as the essential activity of the soul, the process by which the soul realizes itself....it is the 'idea of all thoughts', 'the concept of all concepts, form of all forms.' It is the one thought contained in all thoughts, the ground of the possibility of thought itself... It is the power of designo that enables us even to describe what is designo."

Art begins as a visual form of expression from meanings that can be felt through experience (not empirical). To fulfill art, one needs to think and to design what he wants to express. Without making design, art cannot exist in the world. So maybe the highlight here is that design itself is a process of creation and we need to emphasize on the design value itself.

\section{Short History of Graphic Design and Form}

Actually we might never know the history when human kind first did a design process. It might even started by the first humans ever existed. But graphic design itself has territories begun since Guttenberg created the first letterpress machine in the mid $15^{\text {th }}$ century, even long before that in Japan there already existed a high end printing art. But in the educational world, it was begun since 
Bauhaus started in 1919 in Weimar. It was probably the first time graphic design was acknowledged academically and interacted with architecture and art harmoniously. They explore studies about form (read: formalism) from design, architecture, and art. But when they implement graphic design function differently from architecture and others, because of its intangibility that can only see the function value naively. FromThe ABC's of Bauhaus, The Bauhaus and Design Theory (Lupton, 2000) said they discovered the functional way of thinking in a different way.This allows experimentations in graphic design and typography "At first, practical fields of type application were restricted to small, miscellaneous printed matters. With the appointment of Moholy-Nagy in 1923, came the ideas of "New Typography" to the Bauhaus. He considered typography to be primarily a communications medium, and was concerned with the "clarity of the message in its most emphatic form".

This shows that graphic design thinking even in modernism era has allowed extreme explorations, even in a time that is very strict with function. A more important meaning message takes emphatically-correct values from a clarity that is naïve by exploring form. This has been developed widely by graphic designer after the modern era like Stefan Sagmeister with visual questions "Can Design Touch Someone's Heart?" with more focus on relations and re-opening ideal possibilities, methodologies, and graphic design practices itself.

\section{Design as a Language}

Maybe this is one of the directions to a better explanation about graphic design. Many questions why design is a language, and why a design language is needed. Verbal and written language we use daily is very limited and design language can give more experience. When we discuss experience, this is when art surfaces. And this is the proof that design and art are inseparable words. We cannot do a communication process clearly and maybe this point is the one that designers or teachers are lacking to understand and do in their daily practices because of the rarely-used visual language. Before this, we learn "reading" visual language, but we rarely use it to communicate. And when designers try to visually "speak", referring to the reality that makes its content merely as a representation of reality but not in the process of its creation itself. A basic visual language is then left behind and emphasizes occur on contexts that do not speak of design itself. On the 3 stages of language, information > communication > emphatical, the emphatical stage is the place where visuality works. Stefan Sagmeister said "You can have an art experience in front of a Rembrandt... or in front of a piece of graphic design. "In the book of Made You Look (Sagmeister \& Hall, 2001), they explained how design as a relation synthesis, processes methodologically and connectedly to art to gain the heart of the audience of design and art and focus to the subject matter.

\section{Design as a Cultural Act}

The meaning of design itself evolves and design is no longer a representation of culture and reality, but as an act in culture. In the magazineÉmigré essayedition 32 and Around: Cultures of Design and the Design of Cultures (Blauvelt, 1994) said "The relationship between self and others is a two-way street, producing effects on all parties within a power structure that is typically unequal. This "discovery," of others - that moment of first contact between different groups and their subsequent relationships - has been characterized by the French philosopher Jacques Derrida as essentially "violent": "... the anthropological war [is] the essential confrontation that opens communication between peoples and cultures, even when that communication is not practiced under the banner of colonial or missionary oppression."(2) ... This violence occurs at the level of actual, lived experience and at the level of symbolic existence, through words and images; i.e., representations... Design's relationship with cultural identification is a very important, that is to say, financially significant one. The "discovery" of various cultural groups within society coincides with their definition as an audience and as a market." 
It is important to focus on the discovery of relation between design and culture based on synthesis of experience, language, on the diverse life of the multicultural situations that creates new cultures from the process of design engagement itself. This should be implemented in Indonesian context, considering our multicultural situation. We are never a single culture, even a single language, so we must figure out how to implement that in its visual in Indonesian graphic design, not to artificially implement the same thing in a different subject matter.

\section{Design in Indonesia}

From my study above, I am more certain to question if Indonesia has already owned a design process. Even in the worst case scenario, in our economy, design has not been a vital value in the marketing process, which shows Indonesia's economic stage is not even discussing business yet, we are merely merchants. Especially when we discuss design as a part of culture. We have not think "design" in our daily lives. This situation makes it worse to the existence of false myths in the design world. Purely not because of stupidity, but ignorance of the designers themselves, including the teachers.

\section{CONCLUSION}

From that basic thinking, it is concluded that there is many misunderstanding in teachers, writers, practitioners, associations, and graphic design education system in Indonesia. It is very difficult for designer to move forward with no strong basis on design, not to mention the dictatorship in the educational part. It is time that the fundamental understanding of graphic design begins from the academicals' world not only the industrial world. In this information era it should be easier for us to gain information, and begin a proper design discourse.

\section{REFERENCES}

Blauvelt, A. (1995). In and around: Cultures of design and the design of cultures. Emigre, (Online), Jilid1, No. 32 (http://www.emigre.com/Editorial.php?sect=1\&id=23, diakses 15 Feb 2012)

Lupton, E. (2000). The ABC's of Bauhaus, The Bauhaus and Design Theory. Princeton Architectural Press

Sagmeister, S., \& Hall, P. (2009). Sagmeister, Made You Look. Harry N. Abrams.

William, R. (2004). Art Theory: An Historical Introduction. Wiley-Blackwell. 